\section{BEFEKTETÉS ÉS NYUGDÍJ-ELŐTAKARÉKOSSÁG}

Dr. Harsányi Gyöngyi PhD (Miskolci Egyetem ÁJK Kereskedelmi Jogi Tanszék, egyetemi docens)

\section{ÖSSZEFOGLALÓ}

Az állami nyugdíjrendszer jelentőségének és fenntarthatóságának folyamatos csökkenése a kiegészítő nyugdíjrendszerek felé irányította a figyelmet, melyek alapját a befektetések képezik. Így a különböző nyugdíj-előtakarékossági formák jogszabályi hátterének megteremtése mellett sürgető szükség van a befektetési ismeretek szélesítésére az előtakarékoskodók körében. Jelen tanulmányban ennek érdekében a befektetések gazdasági lényegét, a befektetések és befektetők egyes fajtáit és a befektetési alapok legfőbb jellegzetességeit foglalom össze a nyugdíj-előtakarékossági célú megtakarítások nézőpontjából.

\section{SUMMARY}

Importance and sustainability of state pension system continuously decline, that put focus on supplementary pension schemes. The core of supplementary system is the investment. The various forms of retirement savings requires the enhancement of customers' financial and investment education. This study summarizes economic essence of investments, characteristics and categories of investments, investors and investment funds - from the perspective of retirement savings.

Kulcsszavak: befektetés, befektetők, befektetési alap

Keywords: investment, investors, investment fund

\section{JEL: K22}

DOI: $10.18530 /$ BK.2018.1.50

http://dx.doi.org/1018530/BK.2018.1.50

\section{A befektetésekről általában}

A befektetések alapját a megtakarítások képezik. Ez az alaptétel helytálló a nyugdij-előtakarékosság esetében is, melynek minden formája arra irányul, arra ösztönzi az embereket, hogy megtakarításokat képezzenek, majd azt fektessék be. A piacgazdaság működésének és fejlődésének mozgatórugója a gazdaság alanyainál átmenetileg és időszakosan képződő megtakarításoknak a befektetése jövedelmező, de legalábbis jövedelmezőnek ígérkező valamilyen értékálló befektetési eszközbe, instrumentumba.

A piacgazdaság pénzügyi rendszerének elsődleges feladata a gazdaságban keletkező megtakarítások közvetítése a megtakarítások felhasználóihoz. A megtakarítók és a felhasználók közötti tőkeáramlás a pénzügyi piacokon zajlik. Egy működő gazdaság pénzügyi piacait alapvetően két részre szokás osztani. Pénzpiacra, amely a rövid lejáratú (néhány órától egy évig terjedő) ügyleteket felölelő piac, illetőleg tőkepiacra, amely a hosszú (egy évnél hosszabb) lejáratú ügyleteket magába foglaló piac.

Mindkét piacon pénzek cseréje, mégpedig különböző időpontbeli pénzek cseréje folyik: a megtakarítók jelenlegi pénzüket elcserélik a megtakarítások felhasználóinak jövőbeni pénzére. A pénzpiacnak a váltóra, kincstárjegyre, a tőkepiacnak pedig a részvényre, kötvényre, befektetési jegyre, jelzáloglevélre vonatkozó ügyleteit értékpapírpiacnak nevezzük, amely a tőkeközvetítés, a közvetlen tőkeáramlás fő intézménye.

A befektetésekkel természetesen minden esetben bizonyos mértékű kockázat is együtt jár, van olyan befektetés, amellyel több, van, amellyel kevesebb. Az egyes értékpapírok is (amennyiben értékpapír a befektetési eszköz) a legkülönbözőbb kockázatot és a legkülönbözőbb hozamot testesítik meg, és a tőkepiac az, ahol a kockázat és a hozam közötti átváltás lejátszódik. ${ }^{1} \mathrm{~A} z$ egyes befektetési lehetőségekkel járó kockázat mértéke is állandó mozgásban van, és azonnal reagál a gazdaság működésében beálló változásokra, annak működési zavaraira.

A befektető végezheti személyesen a befektetési műveleteket, és végeztetheti befektetési szolgáltatókkal. A befektetésekkel járó kockázat teljesen nem küszöbölhető ki, de valamelyest csökkenthető, ha a befektető nem maga próbál befektetési tevékenységet folytatni, hanem olyan intézményeket bíz meg pénze elhelyezésével, amelyek kifejezetten befektetési tevékenységre, befektetési szolgáltatások nyújtására szakosodtak. Ezek a speciálisan erre a célra létrejött befektetési intézmények jutalék ellenében vállalják, hogy a befektetők pénzét, megtakarításait a velük kötött szerződés feltételeinek megfelelően magas szakértelemmel fektetik be a gazdaság különböző szférájában működő üzleti vállalkozásokba, értékálló és értéknövelő eszközökbe, értékpapírokba. 


\section{A befektető fogalma és kategóriái}

A befektetésre irányuló ügyletek minden formájában a befektetőé a központi szerep, hiszen az ő tőkéjére, pénzére, megtakarítására van szükség a különböző tőkepiaci műveletek megvalósításához. A befektető fogalmát és kategóriáit jelen cikk elsősorban a tőkepiaci szabályozás irányából közelíti meg. Szükséges ugyanakkor megjegyezni, hogy a befektető fogalma értelmezhető a banki vagy biztosítói szabályozás irányából is, amely esetekben a befektető szükségszerűen egy intézményi befektetőre bízza a pénzét, mint banki ügyfél vagy a biztosított szerződő. Tény ugyanakkor, hogy ezen intézmények fö tevékenysége nem maga a befektetési szolgáltatás nyújtása, hanem a banki, illetve biztosítói tevékenység végzése, a befektetési tevékenység ezen fő tevékenység kiegészítőjeként jelentkezik. Ezen koncepció jegyében az írás tehát nem foglalkozik az egyéb pénzügyi eszközökkel, melyek szintén alkalmasak nyugdíjcélú megtakarításra (biztosítás, pénztári termék)

Az értékpapírjog területére tartozó jogszabályok meghatározzák a befektető általános fogalmát, mely szerint befektető az, aki a befektetési alapkezelővel vagy más befektetővel kötött szerződés alapján saját vagy más pénzét, egyéb vagyontárgyát részben vagy egészben a tőkepiac, illetve a szabályozott piac, a tőzsde hatásaitól teszi függővé, vagyis kockáztatja. Ezen az általános fogalmon belül a 2001. évi CXX. számú tőkepiaci törvény (továbbiakban: Tpt.) elkülöníti az intézményi befektető kategóriáját. Ezek a szervezetek befektetések kezelésével hivatásszerüen foglalkozó jogi személyiséggel rendelkező befektetők, amelyek fötevékenysége a pénzügyi eszközökbe történő befektetés, illetve pénzügyi eszközök értékpapírosítása.

A Tpt. szerint intézményi befektetőnek minősül a biztosító, az önkéntes kölcsönös biztosító pénztár, a magánnyugdíjpénztár, a foglalkoztatóinyugdíj-szolgáltató intézmény, az egészségbiztosítási szerv és a Nyugdíjbiztosítási Alap kezeléséért felelős nyugdíjbiztosítási szerv. ${ }^{2}$

A befektetési szolgáltatásokról szóló 2007. évi CXXXVIII. tv. (a továbbiakban: Bszt.) a befektetési jogviszony alanyait nem befektetőnek, hanem ügyfélnek nevezi, ezen belül a szakmai ügyfél kategóriába sorolja azokat a szervezeteket, amelyek a Tpt. szerint intézményi befektetőnek minősülnek. ${ }^{3}$ A két törvény más elnevezéssel ugyan, de egymást átfedő kategóriát alkalmaz.

A befektetők meghatározása, státuszának, pozíciójának tipizálása, elemzése figyelmet kap mind a közgazdaságtudományban, mint a jogtudományban. Jelen írásunkban a befektetői kategóriák meghatározásához Rotyis József művét ${ }^{4}$ tekintjük etalonnak, mivel időtálló rendszerét adja a befektetők közgazdasági tartalmuk és jellegzetességeik szerinti csoportosításának, melyek közül ehelyütt csak a téma szempontjából relevánsakat emeljük ki. Eszerint a befektetők csoportosíthatók a befektetett tőke tulajdona szerint, a befektetés kockázata szerint, a befektetés időtartama szerint, a befektetett tőke nagysága szerint, a tőkepiaci információk megszerzése szerint, valamint a befektetési döntések meghozatala szerint is.

\section{A befektetésre kerülö megtakarítások tulajdona szerin}

A befektetés forrása minden esetben valamely alanyi körnél felhalmozódó megtakarítás vagy pénzügyi eredmény. A befektetők aszerint is csoportosíthatók, hogy befektetéseiket a saját vagy más megtakarításaiból finanszírozzák. E tekintetben magán-, illetve intézményi befektetők különíthetők el.

A magánbefektetők a saját korábbi megtakarításaikat fektetik be, ennélfogva a befektetés nyeresége vagy vesztesége teljes egészében náluk jelentkezik. Ebből következik, hogy a magánbefektetők érzékenyebbek a kockázatok növekedésére, ugyanakkor motiváltabbak is lehetnek a nagyobb kockázat vállalására.

Az intézményi befektetők nemcsak a saját pénzüket, hanem mások megtakarításait is befektetik. Az intézményi befektetők köre jogszabály által meghatározott. Tevékenységüket, működésüket szigorú előírások korlátai között fejthetik ki. Ugyanakkor az intézményi befektetők egyidejűleg „,szakbefektetők”, szakmai ügyfelek is, azaz szakértők, hiszen mélységükben ismerik a tőkepiac mozgásának, alakulásának törvényszerűségeit, és képesek prognosztizálni a piaci folyamatokat és az egyes értékpapírok várható helyzetét, árfolyamváltozását.

\section{A befektetés kockázata szerint}

„A befektetés kockázata annak bizonytalansága, hogy a befektetett pénz mennyivel nő, illetve csökken a befektetés lezárásának időpontjára." ${ }^{5}$ Ebből a szempontból kockázatkerülő befektetők és kockázatelhárító befektetők különíthetők el. A befektetők legnépesebb csoportját a kockázatkerülő befektetők képezik. A befektetők legnagyobb része nem kedveli a kockázatot, holott alapigazság, hogy több nyereséget általában csak nagyobb kockázat árán lehet elérni. Természetesen - mivel a befektetés minden esetben megtestesít valamilyen kockázatot, nincs befektetés kockázat nélkül, így - a kockázatkerülő befektetők is vállalnak valamilyen kockázatot, akár akarnak, akár nem. Az ilyen befektetők megelégszenek a teljesen biztonságos állampapírok hozamával, és ha más értékpapírba fektetnek, nagyon érzékenyen reagálnak a kockázat akár minimális növekedésére is, ilyenkor inkább azonnal továbbadják, még veszteség árán is, minthogy továbbra is megtartsák az adott értékpapírt.

A kockázatelhárító befektető célja, hogy megvédje magát egy-egy tőzsdei termék vagy valamely pénzügyi mutató változásainak hátrányaitól. A befektetőket ezek a változások attól függően érintik kedvezően vagy kedvezőtlenül, hogy a szóban forgó termékkel kapcsolatban más ügyletekből eredően követeléseik vagy tartozásaik állnak fenn. Az ilyen befektetők valamely tranzakciójukból eredő kockázatok ellensúlyozása érdekében kötnek olyan ügyletet, amelynek a kockázatelhárítás a célja. A kockázatelhárító ügylet tehát egy másik ügylet következményeként születik meg. Ideális esetben a kockázatelhárító befektető összesített kockázata alacsonyabb, mint az a kockázatcsökkentő ügylet megkötése nélkül lenne. Természetesen az eredeti ügylet piaca és a kockázatelhárító ügylet piaca között 
szoros kapcsolat van, hiszen a kockázatelhárító céllal kötött ügyletek piacán kialakuló keresleti és kínálati viszonyokat és az árakat az eredeti tranzakció piacának alakulása jelentős mértékben befolyásolja. ${ }^{6}$

A befektetők sajátos csoportját képezik a kockázati tőkebefektetők. „A kockázati tőke olyan tevékenységek végzését teszi lehetővé, amelyeket más finanszírozók nem látnak el a müködésükhöz szükséges tőkével. A kockázati tőkebefektető másként gondolkodik a profitról, mint a hitelező, a lízingbe adó vagy a faktoráló, ezek célja ugyanis az, hogy minden egyes ügylet nyereséges legyen. A kockázati tőkebefektető azonban nem egyesével szemléli a befektetéseket, hanem csoportokban, tudomásul véve, hogy lesznek olyan befektetései is, amelyek kapcsán elveszíti a befektetett összeget, ugyanakkor lesznek extraprofitot eredményező ügyletei is, amelyek kiegyenlítik ezt a veszteséget. A kockázati tőkebefektetés a társaságokhoz tulajdonosként történő csatlakozás speciális esete. Többnyire nem az alapításkor kapcsolódik be a pénzforrásokkal rendelkező személy, hanem már létező társaságban szerez tulajdonrészt, többnyire jelentős tulajdoni hányadot. A kockázati tőkének az a gazdasági szerepe, hogy olyan tevékenységeket finanszírozzon, amelyek más módon nem vagy csak nagy nehézségek árán jutnának forrásokhoz, így a kockázati tőketársaságok speciális tevékenysége révén olyan céltársaságok is pótlólagos forráshoz juthatnak, amelyek más jogi eszközökkel (hitel, lízing, faktoring) nem juthattak extra tőkéhez a magas tőkeigény, nagy kockázat, hosszú megtérülési idő miatt.”7

\section{A kockázati tőkének az a gazdasági szerepe, hogy olyan tevé- kenységeket finanszírozzon, amelyek más módon nem jutnának \\ forrásokhoz.}

A befektetésekkel járó kockázat tekintetében jelentőséggel bír a befektetési szektorban köthető ügyletek szerinti csoportosítás is. Eszerint egyedi és kollektív befektetéseket különböztethetünk meg.

Az egyedi befektetések körébe a befektetési vállalkozással létrehozott, befektetési szolgáltatásokra, illetve kiegészítő befektetési szolgáltatásokra irányuló jogügyleteket soroljuk, melyek keretében a lakossági vagy szakmai ügyfél egyedi vagy keretszerződés körében teljesítendő megbízásokat ad a befektetési vállalkozásnak. Ebben az esetben az ügylettel összefüggő kockázat teljes mértékben a megbízó ügyfeleket terheli. Ezzel szemben a kollektív befektetési forma, melybe a befektetési alapokba történő befektetéseket, a befektetési alapokkal létrehozott jogviszonyt soroljuk, lényegesen biztonságosabbnak tekinthető abból szempontból, hogy ebben az esetben a vagyont arra szakosodott cégek kezelik, de amennyiben a termék nem rendelkezik tőke-, illetve hozamgaranciával, akkor itt is az ügyfél viseli a befektetési kockázatot. ${ }^{8}$

\section{A befektetés idötartama szerint}

A befektetések általánosságban három időtávra szólhatnak: lehetnek rövid távú befektetések, közép-, illetve hosszú távú befektetések. Ezeken az időtávokon belül is tovább oszthatók. „E tekintetben a néhány perces befektetésektől egészen a többéves, esetleg több évtizedes befektetésig terjed a skála."

Napi befektetők rendkívül rövid távra fektetnek be, melyek közé közé tartoznak a tőzsdei kereskedés sajátos szereplöi, akik a napon belüli, viszonylag kis mértékű ármozgásokat is kihasználva általában sok üzleten igyekeznek összességükben nyereségre szert tenni. A befektetők legszélesebb csoportját képezik a középtávra befektetők. A befektetők zöme nincs olyan helyzetben, hogy napi befektetőként lépjen fel, ugyanakkor a befektetők legnagyobb tömege nem hajlandó hosszú évekig várni arra, hogy befektetése „beérjen”. Erre a tényre voltak tekintettel a jogalkotók is, amikor az egyes értékpapírok futamidejét meghatározták, ugyanis a középtávú értékpapírok a legelterjedtebbek.

Hosszú távra befektetők a befektetőknek olyan csoportja, akik nagyon hosszú ideig, több évig, évtizedig képesek kivárni, hogy befektetésük beérjen. A nyugdíjcélú befektetések értelmszerűen ebbe a csoportba tartoznak. Az ilyen befektetők a kisebb árfolyammozgásokkal nem törődnek, azonban nem nézik, és nem is nézhetik ilyenkor sem tétlenül a piacot, adott esetben készen kell állniuk arra, hogy meghozzák a szükséges befektetői döntéseket.

\section{A befektetett tőke nagysága szerint}

A befektetett tőke nagysága szerinti megkülönböztetés, miszerint a tőkepiacon kisbefektetők, illetve nagybefektetők szerepelnek, meglehetősen relatív, az idő elörehaladtával és a gazdaság erősödésével, a piac fejlődésével állandóan változik. Ezen túlmenően a megcélzott értékpapírok fajtáitól is függ. A kis- és nagybefektetői státusz összefügg a magán-, illetve intézményi befektetői státusszal is, bár nem abszolút módon. Az esetek túlnyomó többségében a magánbefektetők jelennek meg kisbefektetőként a piacon, az intézményi befektetők pedig nagybefektetőként. Az intézményi befektetők egyetlen döntésükkel nagyobb pénztömeget tudnak megmozgatni, mint a magánbefektetők többsége (együttesen)

A tökepiaci információk megszerzése szerint

A befektetések piaca egyre inkább nemzetközi piac. Ezért növekszik a jelentősége annak a megkülönböztetésnek, hogy az információk megszerzése és a befektetési döntések végrehajtása szempontjából milyen közel van a befektetés értékét meghatározó eseményekhez, vagyis azokhoz a piacokhoz, ahol a befektetések adásvétele folyik. 
„A hazai befektetők általában több és gyorsabb információval rendelkeznek a befektetés értékét meghatározó tényezőkről, ami lehetővé teszi, hogy olyan információkat is felhasználjanak, amelyek ugyan nyilvánosak, ám a sokszor sajátos helyi összefüggések miatt a külföldi befektetők számára semmit sem mondanak a befektetések várható értékéről."10

Megítélésem szerint a befektetések értékének alakulására ható információk megszerzése mint osztályozási szempont, nemcsak a hazai és külföldi befektetők közötti különbségtételre alkalmas, hanem a hazai befektetők körén belüli elhatárolásra is. Bár hazánkban igen korlátozottak a szakirodalmi források a bennfentes kereskedelem tárgykörére vonatkozóan, kijelenthető, hogy a bennfentes kereskedők nehezen érhetők tetten. Az is kellő súllyal állítható, hogy a hazai befektetőkön belül is mindig volt és lesz is különbség a befektetések értékére, különösen az értékpapírok árfolyamváltozására vonatkozó információk gyors megszerzésének lehetősége szempontjából.

\section{A befektetési döntések meghozatala szerint}

Aszerint, hogy a befektetők mennyire tudatosan hozzák meg a befektetéseikre vonatkozó döntéseket, a szakirodalom különbséget tesz aktív és passzív befektetők között. Az aktív befektetők az adott befektetésük piacának széles körü elemzése alapján döntik el, hogy mely befektetésüket adják el, illetve milyen befektetéseket, értékpapírokat vásárolnak. Az adott befektetési piac elemzése körében megszereznek minden lehetséges információt mind a befektetési eszközökre, mind az értékpapírok kibocsátójára vonatkozóan. Az intézményi befektetők nyilvánvalóan az aktív befektetők körébe sorolhatók.

A passzív befektetőt befektetési döntéseinek meghozatalában nem befolyásolják tudatos elemek. Nem igyekszik beszerezni a célzott befektetésére vonatkozó információkat, nem végez előzetes elemzést. Alapvetően intuitív módon választja ki a neki tetsző értékpapírt, egyéb befektetést. A magánbefektetők egy - remélhetőleg egyre kisebb - része tartozik a passzív befektetők körébe.

\section{Befektetési alapok}

A nyugdíj-előtakarékossági célú befektetések megvalósítására csak meghatározott értékpapírok alkalmasak. Az egyedi kibocsátású értékpapírok (csekk, váltó, közraktári jegy) természetszerủleg nem jöhetnek számításba, kizárólag a sorozatban elöállított értékpapírok. Ilyenek a részvény, a befektetési jegy, a kötvény, a kincstárjegy, a jelzáloglevél. Ezek az értékpapírok tárgyai lehetnek mind az egyedi, mind a kollektív befektetéseknek. A továbbiakban a befektetési alapokat mint nyugdíj-elötakarékosság céljára is alkalmas befektetési formákat vizsgáljuk. (A befektetési jegyeket legnagyobb hatékonysággal akkor lehet nyugdíj-előtakarékosság céljára használni, ha az ügyfél igénybe veszi a NYESZ által biztosított adókedvezményt.)
A befektetési alap létrehozása befeketési jegyek kibocsátása útján valósul meg. A befektetési alap ugyanis befektetési jegyek nyilvános vagy zártkörű kibocsátásával létrehozott, önálló jogi személyiséggel rendelkező elkülönült vagyontömeg. A befektetőknek a befektetési alappal szemben fennálló követelését, a közös vagyonból őket megillető részesedését és egyéb jogait a befektetési alap által forgalomba hozott befektetési jegy testesíti meg. A befektetési jegyek forgalmazásával összegyűjtott tőkéből a befektetési alapkezelő befektetési eszközöket (értékpapírokat, ingatlanokat) vásárol, melyből portfóliót alakít ki befektetési politikájának megfelelően. Legegyszerűbb megközelítésben tehát a befektetési alapkezelő összegyűjti a kisbefektetők kis megtakarításait, és ebből nagyban vásárol portfóliót, melyen belül azután az alap müködtetése során úgy változtatja a befektetési eszközök, az egyes értékpapírok részarányát, hogy abból a legtöbb hozamot érje el.

A befektetési alap vagyona a befektetők közös tulajdonában van. Az alap vagyona tükrözi a benne lévő befektetési eszközök aktuális piaci értékét, ez a nettó eszközérték. A nettó eszközérték már az alap kezelése során felmerülő összes költséggel csökkentett befektetési értéket mutatja. Azt, hogy a vagyonból adott időpontban mennyi jut egy befektetési jegyre, az egy jegyre jutó nettó eszközérték (a befektetési jegy árfolyama) mutatja meg.

\section{A befektetési alapok típusai}

A befektetési jegyek forgalomba hozatali módja alapján nyilvános vagy zártkörü befektetési alap hozható létre. A befektetők köre alapján szakmai vagy lakossági befektetőknek forgalmazó befektetési alapról, a befektetési jegyek visszaválthatósága szerint nyíltvégű vagy zártvégü befektetési alapról beszélhetünk.

A nyíltvégű befektetési alap befektetési jegyeit a befektetők a folyamatos forgalmazás során az alap futamideje alatt visszaválthatják. Ezzel szemben a zártvégü befektetési alap befektetési jegyei az alap futamideje alatt a befektetők kezdeményezésére nem válthatók vissza. ${ }^{12}$

A futamidő alapján határozott vagy határozatlan futamidővel működő befektetési alap hozható létre.

A befektetési alap által megszerezhető elsődleges eszközök alapján értékpapíralap, ingatlanalap, kockázati tőkealap és magántőkealap különböztethető meg. Az értékpapíralapok és az ingatlanalapok befektetési jegyei szakmai és lakossági befektetőknek egyaránt forgalmazhatóak.

A kockázati tőkealap olyan zártvégű (vissza nem váltható befektetési jegyek zártkörű forgalomba hozatalával létrehozott), alternatív befektetési alap (ABA), amelyet vállalkozásfejlesztés finanszírozásának céljából hoztak létre, és befektetési politikája szerint az összesített tőke-hozzájárulása és a le nem hívott tőkéje legalább 70 százalékát a vállalati fejlődés kezdeti szakaszában lévő vállalkozásokba fekteti, és 
amely - legalább hat teljes naptári éves határozott futamidőre ${ }^{13}$ - kizárólag szakmai befektetők részére hozható forgalomba.

A magántőkealap pedig olyan zártvégű $\mathrm{ABA}$, amelyet vállalatok, vállalatrészek megszerzésének finanszírozása (ideértve az akvizíciót is) céljából hoztak létre, befektetési jegyeit zártkörűen, kizárólag szakmai befektetők részére hozzák forgalomba.

\section{A legszélesebb mandátummal az abszolút hozamú portfólió menedzserei rendelkeznek.}

A befektetési alapoknak számos egyéb csoportosítása is létezik. Ezek közül legfontosabbak: a részvénytúlsúlyos, kötvény-, pénzpiaci és az abszolút hozamos alapok. A kategória elnevezése lényegében azt is meghatározza, hogy az alapkezelő szakembere mennyire kap széles mandátumot a tekintetben, hogy mibe fektetheti az ügyfelek pénzét. Egy részvénytúlsúlyos alap esetén a vagyon legalább 70-90 százalékát részvényekbe fekteti az alapkezelő, míg a kötvényalapok csak kötvénybefektetéseket valósítanak meg. A fenti két kategóriát különböző arányokban lehet keverni, ezeket hívják vegyes alapoknak. A legszélesebb mandátummal az abszolút hozamú portfólió menedzserei rendelkeznek. Ök gyakorlatilag bármilyen instrumentumba fektethetnek, lehet az akár deviza, kötvény, részvény vagy egyéb derivatív termék. Ebben az esetben a befektető lényegében szabad kezet ad pénzének kezelésére, nincs előre meghatározott befektetési stratégia, a befektetés összetétele csak a befektetési alapon múlik. Ebben az esetben különösen fontos a megfelelő befektetési alapkezelő kiválasztása.

\section{A befektetési alapok előnyei}

A befektetési alapok mint kollektív befektetési formák karakteres előnyöket realizálnak az egyedi befektetésekkel szemben. A befektetési alapok különböző fajtáinak bemutatása kellően bizonyítja, hogy nagyon sokszínü és változatos ez a paletta, amely alkalmas a legkülönbözőbb befektetői igények kielégítésére, ráadásul a befektetési alapok által biztosított előnyök minden típusra egyaránt jellemzőek.

E befektetési formának az egyik legnagyobb előnye a kiegyenlített kockázatvállalás, mivel az egyes értékpapírok árfolyammozgásából adódó kockázat megoszlik a különböző értékpapírokba történő befektetés és a résztulajdonosok nagy száma miatt.

A megtakarítások különböző befektetési eszközök közötti megosztásával (diverzifikálással) a portfólió kockázata anélkül csökkenthető, hogy annak várható hozama csökkenne. Minél több eszközből állítjuk össze a portfóliót, a kockázatcsökkenés annál nagyobb lehet (amennyiben az egyes eszközök árfolyama nem mozog együtt). Az egyedi befektetések ilyen szintű kockázatmegosztására a legtöbb esetben nem képesek, leginkább az egyedi portfólió méretéből adódóan, az alapkezelők azonban végre tudják azt hajtani. Előnyt jelent az is, hogy egy alapkezelő társaság keretében szakemberek végzik ezt a munkát - az alap nevében, de a befektető érdekeinek megfelelően, az elérhető legnagyobb hozam biztosítása végett -, megfelelő információ és szakértelem birtokában. A tőkepiacok jelenlegi fejlettségi szintje mellett az optimális befektetési döntések meghozatalához már szinte nélkülözhetetlen a szaktudás, és az alapkezelők tudják ezt biztosítani. Jelentős előnyként értékelhető, hogy a törvény szigorú, garanciális szabályokat állít fel a kisbefektetők érdekeinek védelmében. Előnynek minősül a költséghatékonyság is, mivel bizonyos befektetési összeg alatt egyszerűen nem éri meg közvetlen módon egyedi értékpapírokba fektetni, hiszen az egyedi befektetések relatív költsége így lényegesen magasabb. A befektetések koncentrálásával viszont a költségek jelentősen csökkenthetőek. A nyíltvégű befektetési alapok esetében a likviditás nem kevésbé előnyös, hiszen a befektetők minimális költséggel, rugalmasan tudják adni-venni a befektetési jegyeiket.

Összegezve: a befektetési alap világszerte méltán az egyik legnépszerủbb befektetési termék. A befektetési alapokon keresztül az egyes befektetők (lakossági és intézményi befektetők egyaránt) rendkívül egyszerűen, költséghatékonyan és a kockázatok megosztásával fektethetik be megtakarításaikat a tőkepiacon.

\section{Nyugdíj-előtakarékosság mint befektetés}

Napjainkban az állam által elismert önkéntes előtakarékossági formáknál (nyugdíj-előtakarékossági számla, önkéntes kölcsönös nyugdíjpénztár, magánnyugdíjpénztár, nyugdíjcélú befektetési életbiztosítások), akár a leendő nyugdíjasok - fentieken túli - további megtakarításainál a közös nevezőt a befektetések jelentik. A mai világban tehát a jövőről való gondoskodás, a különböző kiegészítő nyugdíjbiztosítási rendszerek kialakítása és elterjesztése megkívánja a befektetési ismeretek bővítését. Ezt ismerte fel az Európai Bizottság, amikor 2010-ben kiadta a fenntartható és biztonságos európai nyugdíjrendszerek felé vezető útról szóló Zöld Könyvet, majd pedig 2012-ben a Fehér Könyvet, amely a tőkefedezeti finanszírozás, illetve a nyugdíj-előtakarékosság miatt a lakosság befektetési ismereteinek szélesítését, a kiegészítő nyugdíjrendszerek biztonságosságának javítását, a tőkefedezeti rendszerek befektetési kockázatainak szabályozással történő csökkentését írta elő. Ezeknek a céloknak a megvalósítása valóban elengedhetetlen. A különböző előtakarékossági formák mindegyikénél a jövőbeni nyugdíj összege a befizetett összeg mértékén túl a befektetési döntésektől függ, attól, hogy mennyire profitábilis befektetési eszközt, formát sikerül kiválasztani az előtakarékoskodó személynek. Az önkéntes nyugdíjpénztár által működtetett választható portfóliós rendszer esetében például a pénztártagok az egyéni nyugdíjszámlájukon lévő összeget saját döntéstől függően a pénztár által kialakított portfóliók valamelyikébe fektethetik. (Ugyanakkor, ha a tag nem hoz ilyen döntést, akkor a pénztár a tag életkorától, a hátralévő tartamtól függően sorolja be a tagot egy portfólióba.) A tag önálló választásához ismernie kell a különböző értékpapírok, befektetési eszközök jellemzőit, a hozamot befolyásoló tényezőket, a befektetési ügyletek ismérveit. 
A leendő nyugdíjasok befektetési ismereteinek bővítése érdekében az Unió ilyen tárgyú irányelvek és rendeletek körében rendkívüli mértékben kiszélesítette a befektetési szolgáltatások nyújtására jogosult szervezetek, befektetési vállalkozások, hitelintézetek, illetve a befektetési alapkezelők tájékoztatási kötelezettségét. A korábban is már szigorú szabályokat tovább szigorította az európai MiFID és UCITs szabályozások közelmúltban lezajlott revíziója, melyek rendelkezéseit 2018-tól kell alkalmazniuk a piacoknak. Mindezek az előírások nemzeti jogunk részeivé váltak, és egyértelműen a befektetési ismeretek körének kiterjesztését szolgálják. A jogalkotó a Bszt.-ben ${ }^{14}$, illetve a Kbftv.-ben ${ }^{15}$ konkrétan és nagyon részletesen megjelöli azokat az elemeket, amelyekről a befektetőt tájékoztatni kell, a tájékoztatási kötelezettség kiterjed a befektetéssel feltétlenül együttjáró - különböző mértékü - kockázatok jelzésére is, azonban annak tudatosítása, hogy a kockázat mindig a befektetőé, hogy a befektetésünket - hosszú évtizedeken keresztül történő előtakarékosság után - teljes mértében el is veszíthetjük, esetleg éppen akkor, amikor szükségünk lenne rá, nem történik meg. Az a tény ugyanis, hogy megtakarításaink befektetése tekintetében jelenbeni ismereteink alapján hozunk döntést, mely döntésnek az eredménye a jövőben kialakuló gazdasági és egyéb tényezőktől függ, sohasem garantálhatja a sikert. Nem tudatosítják kellő alapossággal azt sem, hogy a befektetési piac nemzetközivé vált, tehát lényegében bármilyen befektetési eszközt választunk, annak eredményessége nem kizárólag a hazai pénz- és tőkepiac jelenségeitől függ, hanem igen erőteljesen befolyásolják a nemzetközi színtér történései is. Végül pedig nem tudatosítják a befektetőkben azt sem, hogy a törvény garanciális szabályai és a tőkepiac feletti állami felügyelet együttesen bármilyen hatékonyan is müködik, nem tudja nullára csökkenteni annak kockázatát, hogy egy befektetési szolgáltató szabálytalan, adott esetben jogsértő módon, a büntetőjog rendelkezéseibe ütközve kezelje a nála lévő ügyfélpénzeket.

Megítélésem szerint a lakosság befektetési ismereteinek bővítése során ezekre az alapvető tényezőkre különös súllyal kell felhívni a figyelmet. Ezt követheti csak a különböző befektetési formák, befektetési eszközök, lehetőségek és a rájuk vonatkozó jellemzők körére irányuló részletes tájékoztatás.

\section{HIVATKOZÁSOK}

'Horváth D. Tamás: A magyar tőkepiac, Közgazdasági és Jogi Kiadó Budapest, 1996. p. 20. ${ }^{2}$ Tpt. 5. $\$ 60$. pont

${ }^{3}$ Bszt. 48-51.\$

“Rotyis József: Tőzsdei befektető̉k kézikönyve CO-NEX Könyvkiadó Kft. 1998.

${ }^{5}$ Rotyis József: Id. mü 15 .

${ }^{6}$ Rotyis József:

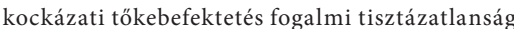

et Politica, Miskolc, Tomus XXI/2. 2003. pp. 647-663.

${ }^{8}$ Lásd a 3.2. pontban kifejtetteket

${ }^{10}$ Rotyis József: Id mü 19 .

"A portfólió különböző befektetési eszközöket (pl. kötvény részvény, befektetési jegy) tartalmazó befektetési csomas

${ }^{12} \mathrm{Ez}$ alól kivételt képeznek a 2014. évi XVI. törvényben biztositott rendkivüli esetek. Az alapkezelő jogosult továbbá a befektetőknek az alap futamideje alatt is eseti jelleggel visszaváltási lehetöséget biztositani, valamint - amennyiben az alap kezelési szabályzata ezt lehetôvé teszi - jogosult a kezelési szabályzatában eredetileg meghatározott feltételek szerint a befektetesi jegyek bevonására.

${ }^{13} \mathrm{~A}$ futamidôt az alapkezelő - ha azt a kezelési szabályzat lehetôvvé teszi - meghosszabbithatja, legfeljebb az eredeti futamidőt nem meghaladó időtartammal.

142007. evi CXXXVIII. számú a befektetési vállal kozásokról és árutőzsdei szolgáltatókról szóló törvény.

152014. evi XVI. számú a kollektív befektetési formákról és kezelöikről szóló törvén

作 s.

tol 作elelnie. A KID dokumentumban indokolt esetben egyértelmű figyelemfelhivás történik a tőkevesztés lehetőségére.

\section{IRODALOMJEGYZÉK}

Horváth D. Tamás (1996): A magyar tőkepiac, Közgazdasági és Jogi Kiadó, Budapest

Rotyis József (1998): Tőzsdei befektető̋k kézikönyve, CO-NEX Könyvkiadó Kft., Budapest

Miskolczi Bodnár Péter (2003): A kockázati tőkebefektetés fogalmi tisztázatlansága, Sectio Juridica et Politica, Tomus XXI/2., Miskolc

Szalai Péter (2015): A kiegészitỏ nyugdijirendszerről az állami ellátás tükrében, Biztositás és Kockázat, 2.évf. 2. sz. pp. 26-47.

Lencsés Katalin - Paál Zoltán (2015): Több vagy jobb minőségú tájékoztatás a befektetési temékek piacán? Biztosítás és Kockázat 2.évf. 3. sz. pp. 12-29.

Tomori Erika (2016): Értékpapírjog és a tỏkepiac szabályai, Közép-európai Brókerképző Alapitvány, Budapest http://penzugyi-tudakozo.hu/befektetesek-tipusai-kockazatai-jellemzoi/ 